\title{
Migrant Remittances and Health Outcomes in the West Africa Monetary Zones (WAMZ)
}

\author{
Iseghohi Judith Omon ${ }^{1}$
}

\begin{abstract}
This study investigated the impact of international migrant remittances on life expectancy rate for countries of West Africa Monetary Zones (W AMZ). Panel data set for the period (1990-2020) were used for the analysis. The study estimated pooled ordinary least square, fixed effect models, random effect models and pooled mean group estimate. The pooled mean group estimates showed that migrant remittance as a share of the gross domestic product has significant positive impact on life expectancy rate in both short and longrun. The result showed that in the, a 1\% increase in migrant remittance as a share of the GDP will cause life expectancy rate to rise by $4.003 \%$ in the short-run, but $9.896 \%$ in the long-run. Other factors which include per capita income, HIV/AIDS and out-of-pocket health spending all significantly influence life expectancy rate at birth. We recommend that policies should be articulated that will incentivize remitting money home, and that the costs of remitting money bome should be made less, while the channels improved on.
\end{abstract}

Keywords: remittances, health outcomes, West Africa Monetary Zone

JEL Codes: F24, F29, O55

DOI: $10.24818 / \mathrm{REJ} / 2021 / 81 / 02$

\section{Introduction}

All developing countries are characterized with shortage of savings, foreign exchange, public revenue and human capital skills. Contemporary theories of growth and development recognized these variables as key drivers of economic growth and development. In the light of the severe inadequacy in the supply of these key inputs, remittances have been recognized as alternative source of supply of critical development inputs (Iseghohi, 2020a). Remittances send to families at home now account for a reasonable source of household income (Uzochukwu \& Chukwunonso; 2014; Iseghohi, 2020b). This makes available the needed funds to engage in subsistent farming and other non-Agricultural investment opportunities that are necessary for households to break out of the vicious circles of poverty, and improve health and educational attainments (Uzochukwu \& Chukwunonso; 2014).

\footnotetext{
${ }^{1}$ Department of Economics, Faculty of Social Sciences, University of Benin, Edo State, Nigeria. e-mail : judithiseghohi@yahoo.com
}

Year XXIV no. 81

September 2021 
The inflow of migrant remittances is considered an essential indicator of the economic benefits of migration as a weapon to ward off poverty. Evidence from World Bank (2016) and other multilateral institutions showed that migrant remittance has experienced noticeable increase over the years (Iseghohi, 2020b). Estimates have showed that remittances increased from USA \$93 billion in 2003 to USA $\$ 300$ billion in 2010. A large portion of world remittance flows goes to developing countries. The evidence shows that there has been a disproportionate flow of world remittance flows among developing countries, with Latin America and the Caribbean, East Asia and the Pacific and South Asia as the largest recipients of global international remittance (Adams, 2007; Uzochukwu \& Chukwunonso; 2014). By contrast, sub-Saharan Africa receives less than $5 \%$ of global international remittance (Adams, 2007; Iseghohi, 2021). African migrants sent home close to USA $\$ 60$ billion as remittance home to families and friends. With dearth of opportunities in Africa, many households depend on remittances for improved access to health care services (Iseghohi, 2020a; Iseghohi, 2021).

An interesting aspect of the debate is the role which remittance plays in enhancing health and educational attainment among recipient nations. Remittances are associated with increased household investments in education and health and all these have high social return in many circumstances. Studies in Srilanka and Elsalvador found out that children from remittance-receiving homes have higher birth weight compared to those from non-receiving homes. Studies in Armenia and Mexico reported that remittances were associated with higher healthcare spending (Amuedo-Dorantes \& Pozo, 2009; Murrugarra, 2002; Nathaniel, 2019).

Considering the interaction between health and migrant remittance and the fact that West Africa Monetary Zones (WAMZ) has received increasing amount of international migrant remittance, but abysmally has demeaning health outcomes, it is pertinent to explicate the nature of relationship that exists between health and migrant remittances in the WAMZ. This study provides an empirical base on the relationship between migrant remittances and health outcomes in the WAMZ.

The rest of the paper is structured as follows: after the brief introduction, section 2 exposes an over view of remittance flow and trends over the years. Section 3 focuses on the empirical literature and theoretical framework. Section 4 presents the theoretical framework and method of analysis. Section 5 presents the results and finally section 6 dwelt on the conclusion and policy recommendations.

Year XXIV no. 81

September 2021 


\section{Overview of Remittance Flow}

It has been widely acknowledged that cross border movement of persons and goods have been a global phenomenon over the years. With particular reference to human movement, about 3 percent of the world's population is counted as migrants (Harrison, 2004). This movement in persons has resulted in several issues amongst which are remittances flows. Remittances, as a concept in international capital movement, have been a part of human history. For example many European countries such as Spain, Italy and Ireland depended largely on remittances in the 19th and 20th centuries for growth and development. Spain was the first country to sign an international treaty to reduce the cost of remittances received in 1940s followed by Argentina in 1960 while Italy initially promulgated a law to protect remittances in 1901(Harrison, 2004).

Over the years, remittances flow to poor regions of the world experienced a tremendous increase reaching about $\$ 93$ billion in 2003 but fell within the range of about $\$ 200$ and $\$ 300$ billion in 2010 (Ratha, 2011). Gupta and Waghs (2007) reported that official remittances to emerging market economies reached a total of $\$ 188$ billion in 2005. This is twice the amount of development assistance received by the economies, while informal and unreported figures between 2000 and 2005 added up to about $\$ 94$ billion. In particular, remittances to developing countries grew steadily, reaching an estimated $\$ 404$ billion in 2013, $\$ 436$ billion in 2014, which was about 4.4 percent over the 2013 period (World Bank, 2014). In 2015 and 2016, remittances inflow to developing countries amounted to about $\$ 440$ billion and $\$ 479$ billion respectively owing to the positive global economic outlook (World Bank Global Economic Prospects, 2016).

This sustained steady increase in remittances flow to most developing countries informed the decision of World Bank to identify international remittances as one of the main sources of external finance to these developing countries in 2011. In particular, World Bank (2014) placed remittances as the second largest source of external finance inflows to developing countries

Adolfo, Chami, Fullenkamp, Gapen and Peter (2009) stated that remittances inflows on the average amounted to about 35 percent of export earnings and have become as large as foreign direct investment to developing countries in Latin America. Similarly, official figures from the World Bank's World Development Indicators (2015) reveal that in WAMZ countries, remittances outweigh inflow of foreign direct Investment (FDI) and Official Development Assistance (ODA). This increase could be attributed to the upsurge in migrants mainly from WAMZ

Year XXIV no. 81

September 2021 
which is usually accompanied with high remittances inflow to home countries (World Bank, 2015). The huge inflow of remittances to WAMZ could also be linked to high migration, poor standard of education, political instability, ethnoreligious crisis, economic downturn and so on (DFID, 2004; Carling, 2008).

High migration tends to attract higher remittances; also poor standard of education also correlates low wages. The same applies to political instability which tend to encourage more remittances for sustainance and make people move to a more peaceful zone (Carling, 2004).

Migration and Remittances Fact book (2011) indicated that total remittances inflows to Nigeria in 2007, 2008, 2009 and 2010 was approximately \$9billion each year. It also shows that top source countries for Nigerian remittances are the United States, United Kingdom, Chad, Cameroun and Italy.

Also, Quartey (2006) revealed that remittances are becoming potential sources of foreign exchange in Ghana. Remittances exceeded ODA inflow to Ghana and as at 2008, total remittances flows to Ghana stood at about\$1.9billion (Bank of Ghana 2009). Similar upward trend in remittances inflow had also been reported in other WAMZ countries such as Liberia, Gambia, Sierra Leone and Guinea in recent times.

\subsection{Trend in Remittances Flows}

Though, other sources of remittances inflows to a country abound, a larger proportion of remittances inflow to countries of the world are linked to migrant workers who reside in different countries across the globe. An attempt is made here to establish the countries or sub-region which accounts for a larger proportion of remittances flows globally.

Table 1. Global Top Ten Recipient Countries of Remittances (in billions of US \$)

\begin{tabular}{|l|r|r|r|r|r|r|r|r|}
\hline \multicolumn{1}{|c|}{ Countries } & $\begin{array}{r}\text { Rem* } \\
\mathbf{2 0 0 9}\end{array}$ & $\begin{array}{c}\text { Rem* } \\
\mathbf{2 0 1 0}\end{array}$ & $\begin{array}{c}\text { Rem* } \\
\mathbf{2 0 1 1}\end{array}$ & $\begin{array}{c}\text { Rem* } \\
\mathbf{2 0 1 2}\end{array}$ & $\begin{array}{c}\text { Rem* } \\
\mathbf{2 0 1 3}\end{array}$ & $\begin{array}{c}\text { Rem* } \\
\mathbf{2 0 1 4}\end{array}$ & $\begin{array}{c}\text { Rem* } \\
\mathbf{2 0 1 5}\end{array}$ & Total \\
\hline India & 49.2 & 53.48 & 62.5 & 68.82 & 69.97 & 70.97 & 72.2 & 447.14 \\
\hline China & 41.6 & 52.46 & 61.58 & 57.99 & 59.49 & 61.49 & 63.9 & 398.51 \\
\hline Philippines & 19.96 & 21.56 & 23.05 & 24.61 & 26.7 & 27.9 & 29.7 & 173.48 \\
\hline Mexico & 22.08 & 22.08 & 23.59 & 23.37 & 23.02 & 24.5 & 25.7 & 164.34 \\
\hline France & 16.06 & 19.46 & 22.56 & 22.05 & 23.34 & 23.94 & 24.6 & 152.01 \\
\hline
\end{tabular}

Year XXIV no. 81

September 2021 


\begin{tabular}{|l|r|r|r|r|r|r|r|r|}
\hline \multicolumn{1}{|c|}{ Countries } & $\begin{array}{c}\text { Rem* } \\
\mathbf{2 0 0 9}\end{array}$ & $\begin{array}{c}\text { Rem* } \\
\mathbf{2 0 1 0}\end{array}$ & $\begin{array}{c}\text { Rem* } \\
\mathbf{2 0 1 1}\end{array}$ & $\begin{array}{c}\text { Rem* } \\
\mathbf{2 0 1 2}\end{array}$ & $\begin{array}{c}\text { Rem* } \\
\mathbf{2 0 1 3}\end{array}$ & $\begin{array}{c}\text { Rem* } \\
\mathbf{2 0 1 4}\end{array}$ & $\begin{array}{c}\text { Rem* } \\
\mathbf{2 0 1 5}\end{array}$ & Total \\
\hline Nigeria & 18.37 & 19.82 & 20.62 & 20.63 & 20.89 & 20.88 & 20.89 & 142.1 \\
\hline Egypt & $\mathbf{7 . 1 5}$ & 12.45 & 14.32 & 19.24 & 17.83 & 19.83 & 20.4 & 111.22 \\
\hline Germany & 12.34 & 12.79 & 14.52 & 15.14 & 15.2 & 16.6 & 17.5 & 104.09 \\
\hline Pakistan & 8.72 & 9.69 & 12.26 & 14.01 & 14.63 & 17.8 & 20.1 & 97.21 \\
\hline Bangladesh & 10.74 & 11.28 & 12.96 & 14.24 & 13.86 & 15.1 & 15.8 & 93.98 \\
\hline
\end{tabular}

Source: World Bank Data (2015)

Note: Rem* represents Remittances

World Bank (2015) estimate revealed that remittances totaled about US $\$ 414$ billion in 2009, of whichUS\$316 billion went to developing countries. This estimated value of remittances flows to a large extent was linked to about 192 million migrant workers worldwide. Table 1 above shows that between 2009 and 2015, India topped as the highest remittances recipient country in the world with a total of $\$ 447.14$ billion. It is closely followed by China with $\$ 398.51$ billion. Philippines, France, Mexico, Nigeria, Egypt, Germany, Pakistan and Bangladesh followed in a descending order. These huge remittances inflow to India and China could, among others, be mainly attributed to the strength of their migrant population spread across different countries of the world (Ratha, 2011). With respect to Africa, it should be borne in mind that data on remittances are largely not comprehensive due to the informal medium mainly employed. However, huge amount of remittances to African Countries emanates from migrants pegged between 20 and 30 million persons sending about $\$ 40$ billion USD annually to their families and local communities back home. Table 1 show that Nigeria is the only WAMZ country that makes the top ten global recipient countries occupying the $6^{\text {th }}$ position between 2009 and 2015. Closely following Nigeria is Egypt a North Africa country in the $7^{\text {th }}$ position (see table 1 for details). 
Table: 2. Top Ten Remittances Recipient Countries in the World as at 2016

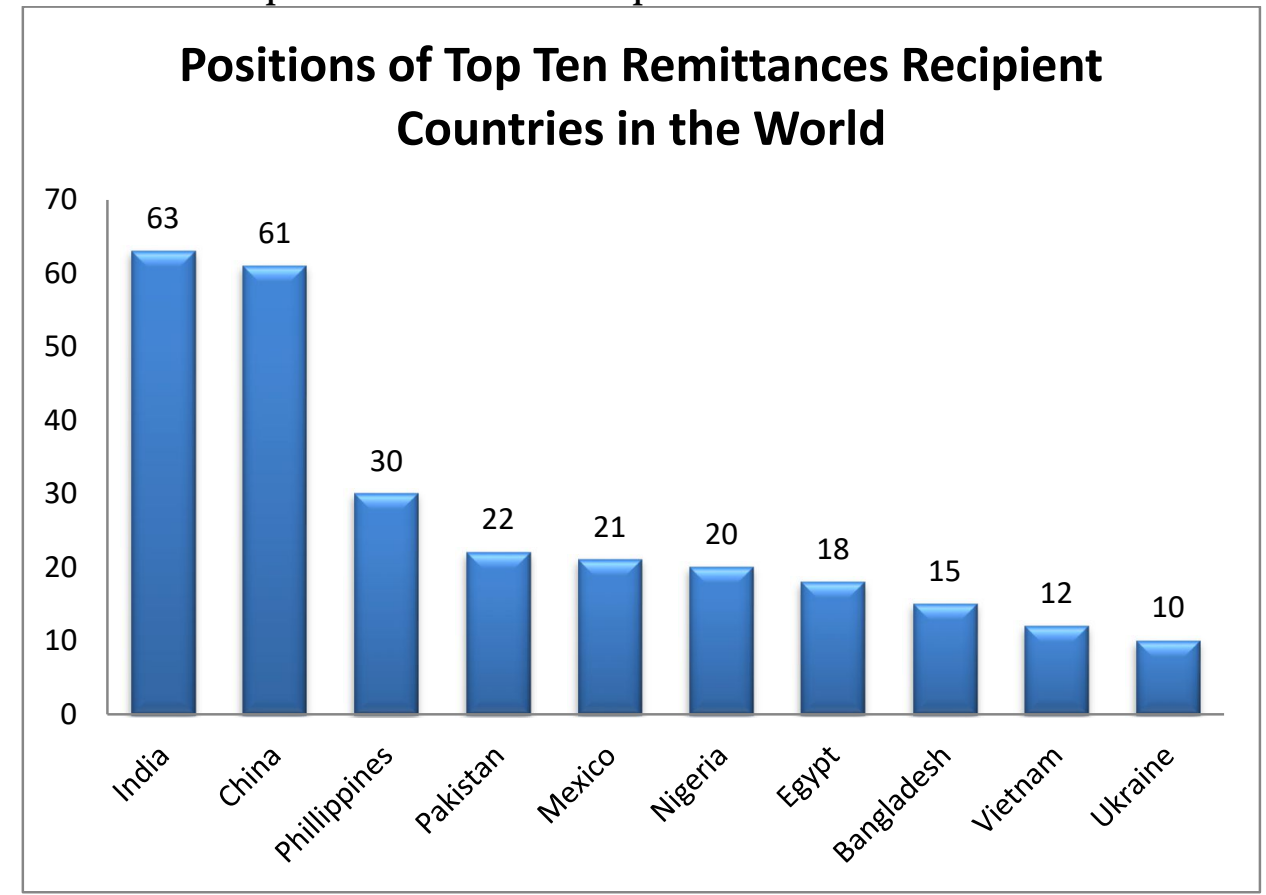

Source: Migration and Remittances Fact book 2016

Table 1 shows the top ten remittances recipient countries in the world as at 2016. It shows vividly the variation that exists in remittances flow among the top recipient countries globally in comparison to previous years as revealed in 1 . The figure shows that there was a slight difference compared to what exists in Table 1. The first three top remittances recipient countries comprising India, China and Philippines retained their positions. Pakistan which was initially in the $9^{\text {th }}$ position in Table 2.1climbed to $4^{\text {th }}$ position while Mexico moved down from $4^{\text {th }}$ in Figure 1 to the $5^{\text {th }}$ position in figure 1.The two top African countries of Nigeria and Egypt retained their positions of $6^{\text {th }}$ and $7^{\text {th }}$ respectively in figure 1 and 2.2 while Bangladesh move two points up to occupy the $8^{\text {th }}$ position in Table1 compared to $10^{\text {th }}$ position in figure 1 .Vietnam and Ukraine which were new entrants occupied 9th and $10^{\text {th }}$ positions respectively. A cursory look at figure 1 shows that some countries such as India, China, Nigeria, Egypt and Bangladesh recorded marginal fall in amount recorded as remittances compared to 2015. This could be linked to the high level of oscillations that characterize remittances flows globally. However, on a general note, it can be argued that the top ten global recipients of remittances 
were relatively unstable between 2009 and 2016. Though some of them maintained their positions.

\section{Empirical Literature Review}

Migrant remittances to households generally improve their income level and enhance their standard of living by making more resources available for food, and for utilization of healthcare services. There is a dearth of evidence on the effect of remittances on health and education outcomes, and even the few studies have yielded conflicting findings. While some studies reported positive impact of remittance on health and education, others could not validate the relationship. Research evidence from South Africa reported that children from remittance receiving households have higher school completion propensities compared to non-remittance receiving households (Yao \& Treiman, 2016).

Through their impact on poverty reduction, remittances enable recipient households to improve their access to quality health and education. Murrugarra (2002) examined the effects of remittances on healthcare utilization among 3,600 households in Armenia, drawing upon data from the Integrated Living Standard Survey. The study used censored model. The results showed that 1,000 Armenia Drams (ADM), which is approximately $\$ 2$, enhanced healthcare utilization rates in a very small and insignificant way

Rubyutsa (2002) explored the effect of remittances on healthcare accessibility drawing upon primary data obtained from interview from the Department of Statistics at the National Bank of Rwanda. The study revealed that reasons for remittance include healthcare issues. The impact of remittance on healthcare according to the study is not clear.

Amuedo-Dorantes and Pozo (2009) utilizing national representative households' survey for Mexico examined the effects of remittances on health expenditure. The result showed that $\$ 86.27$ rise in remittance from abroad increases healthcare expenditures between $\$ 0.26$ and $\$ 0.32$.

Reassne, Oswaldo and Dolores (2009) examined the impact of migrant remittances on expenditure for medicines and other health services for Mexico, drawing upon data from the 2006 survey of two localities in the municipal city of Tepoztta and Morelos, utilizing multinomial logistic regression method in the analysis. The results showed that households that received remittances, over twice as may had spent on health than had not (7\% vs. $3 \%)$.

Year XXIV no. 81

September 2021 
Lopez-Cevallos and Chi (2012) explored the impact of remittances on healthcare utilization among 10,813 households that received remittances. The result showed that remittances improved the use of antiparasitic drug after adjusting for predisposing, enabling and need factors.

Uzochukwu, Chukwunonso and Gerald (2014) investigated the impact of migrant remittances on health and education outcomes of 18 sub-Saharan Africa (SSA) countries, using the technique of two-stage least square (2SLS). The result showed that remittances have significant positive influence on health and education outcomes for selected countries. Furthermore, every ten percent increase in remittances resulted in 4.2 percent increase in primary education outcomes, 8.8 percent increase in secondary education outcomes and 1.2 percent increase in health outcomes. Accounting for individual country heterogeneity, the result still maintained that remittances still remain a significant factor in accelerating improvements in per capita income, education expenditure, and health expenditure. Policy implications require that appropriate policies and incentives be implemented to encourage migrant to remit more money home.

Alkabir, Khan and Amm (2018) explored the impact of remittances on healthcare utilization in Bangladesh utilizing quantitative method. Data on total remittances inflow and life expectancy rate at birth (as a proxy for healthcare) were obtained from World Development Indicators. The result showed that in the long-run, there was a positive relationship between remittance and health improvements, while, in the short-run, there was no significant relationship between remittances and health improvements

Ponce, Olivie and Onofa (2018) evaluated the impact of remittances on health outcomes in Ecuador using an instrumental-variable approach. The study could not find significant impact of remittances on long-term child health variables, but revealed that remittances do not have significant impact on health expenditures, and on preventive healthcare such as deworming \& vaccination. Also, there exists significant effect of remittances on medical expenditures when illness occurs. The authors concluded that remittances are used for both preventive and emergency situations. Interestingly, the study found a significant and positive effect of remittances on health knowledge.

However, as impressive and instructive as these studies, they have limited coverage. There is dearth of evidence on remittance on health for SSA and not even one for WAMZ. The findings from past studies cannot be extended to cover African region. The only study that covered SSA that is Uzochukwu and 
Chinonso (2018) did not include life expectancy rate, but rather used public health spending. This study broadened the scope of past studies by undertaking macroeconomic study. Also, very key important variables such HIV/AIDS prevalent rate, Gini coefficient index and Out-of-pocket share in total health spending was used as control variables.

\section{Theoretical Framework}

The health production function has been used in studies that examine the effect of health spending and other socioeconomic factors on health outcomes. The underlying feature of this approach is the concept of the production which assumes that good health is the sole output from the health system, and as such focuses on measuring how the effect of health expenditure, which is an investment into the health system of a nation/society, affects health outcomes in that nation/society.

Thus, the production function provides a link between inputs and outputs from a production unit, given the underlying technology. This is the underlying feature of the health production function. This is the underlying feature of the health production function. The approach views health outcomes as a product or an output from the healthcare system in the nation. Thus, just like any system of production or an output from the healthcare system is also assumed to solely focus on providing or producing good health to the people or population and this is measured in the improvement in health outcomes that is observed over time. This approach has been used in studies conducted by Filmer and Pritchet (1999); Anyanwu and Erhijiakpor (2007), and Nixon and Ulmann (2007), and Sede and Ahuru (2008). This approach considers health care expenditure or health resources and other socioeconomic factors as the inputs and health outcomes measured as the output from the health system.

Studies that have used the production function in the analysis of health outcomes have been based on the Cobb Douglas specification of a production function. These have identified the appropriate socioeconomic inputs, in addition to health expenditure that influences the wellbeing of the population and hence improvement or otherwise of health outcomes. Mortality and life expectancy have been used generally to measure the improvements in health outcomes in such studies. Filmer and Pritchett (1999), one of the studies that explicitly specified the production function, formulated it as,

$\mathrm{HS}=\left(\frac{H i}{N i}\right)^{\alpha} \mathrm{X}\left(\frac{N H i}{N i}\right)^{\beta} \times\left(\frac{H i}{N i}\right) \quad \mathrm{Xe}^{\mathrm{Ai}}$ 
Equation 1 explicitly presents a health production, in the tradition of the CobbDouglas specification, specified by Filmer and Pritchett (1999). HS is a proxy for health outcomes. Hi in the equation is the health expenditure in country $i$ and NHi is the rest of GDP, which according to the authors, includes all non-public sector health spending. NHi is used as a proxy for income in country and e is the natural exponential function. $\mathrm{Ai}$ is a country specific factor. Dividing the numerators through by GDP and taking logs of equation 1 results in equation 2 . This presents the health outcomes in per capita terms in the nation.

$\operatorname{Ln} H S=\alpha \operatorname{Ln}\left(\frac{H i}{N i}\right)+\beta \operatorname{Ln}\left(\frac{N H i}{N i}\right)+\operatorname{Ln}(\alpha+\beta)\left(\frac{G D P i}{N i}\right)$

Equation (2) expresses the log of health outcomes as a function of the log of public health expenditure as a share of the GDP, non-public health sector as a share of the GDP, non-public health sector spending as a share of the GDP (inherently assuming that $\mathrm{H}+\mathrm{NH}=\mathrm{GDP}), \mathrm{GDP}$ per capita and the country specific factor Ai. Further, the authors assume Ai to depend on a set of observable and non-observable socioeconomic factors that are specific to the country and affect health outcomes in the country. This is specified in equation 3

$\mathbf{L n} \mathbf{H S}=\beta 1+\ln \left(\frac{G D P i}{N i}\right)+\beta 2 \ln \left(\frac{H i}{G D P i}\right)+1 \beta 3(\mathrm{Xi})+\mathrm{ei}$

Equation 3 specifies the natural log of health outcomes, which the authors use life expectancy rate as a proxy, as a function of the log of mean per capita income (GDPi/Ni), the log of public health expenditure as a share of the GDP $\left(\frac{H i}{G D P i}\right)$ and other socioeconomic/health factors (Xi). In applying this model, we included the following socioeconomic factors: migrant's remittance as a share of the gross domestic product, HIV/AIDS prevalent rate, food availability index, out-ofpocket spending as a share of total health spending, and Gini coefficient index.

\subsection{Empirical model}

To examine the impact of migrant remittances on health outcomes for WAMZ, the health production function and the outcomes of previous empirical research (see Sede and Ahuru, 2017; Filmer and Pritchett, 2009; Anyanwu and Erhijiakpor, 2009) were used in specifying our empirical model. The functional specification of the model is:

LER $=\mathrm{f}(\mathrm{PRR}, \mathrm{PCI}, \mathrm{HIV} /$ AIDS, FAI, OUTTHE, GINDEX)

Year XXIV no. 81

September 2021 
The stochastic specification of the model is given as:

$\operatorname{LnLER}_{\mathrm{it}}=\beta_{0}+\beta_{1} \operatorname{LnPRR}_{\mathrm{i}, \mathrm{t}}+\beta_{2} \mathrm{LnHIV}$ AIDS $_{\mathrm{i}, \mathrm{t}}+\beta_{3} \operatorname{LnFAI}_{\mathrm{i}, \mathrm{t}}+\beta_{4} \operatorname{LnOUTTHE}_{\mathrm{i}, \mathrm{t}}+\beta_{5} \operatorname{LnGIN}$

$\mathrm{DEX}_{\mathrm{i}, \mathrm{t}}+\mu_{\mathrm{i}, \mathrm{t}}$

Where:

$\mathrm{i}=$ each cross sectional unit (or country);

$\mathrm{t}=$ time;

PRR = Personal remittances received as a percentage of GDP;

OUTTHE = share of out-of-pocket health spending in total health spending;

$\mathrm{FAI}=\mathrm{It}$ is the ratio of average wages to the price of one individual food items

$\mathrm{HIV} / \mathrm{AIDS}=$ the percentage of the population that is HIV/AIDS prevalent rate;

PCI $=$ Per capita income of recipient country;

GINDEX $=$ Gini coefficient index

$\mathrm{Ln}=$ natural logarithm

$\mu=$ Error term.

The a priori expectations are: $\beta_{1}>0, \beta_{2}<0, \beta_{3}>0, \beta_{4}<0, \beta_{5}<0$.

\subsection{Method of analysis}

The nature of the study necessitated the use of panel data for the period 19902018.

\section{Data description}

The study used a panel set for the five countries of WAMZ. The study focuses on countries of WAMZ comprising Nigeria, Gambia, Ghana, Sierra Leone, and Liberia. The period of the study is from 1990 - 2018. This was informed by the availability of data. Also, this period recorded high proportion of migrants from WAMZ and huge increased remittances inflows compared to previous decades (UNDP, 2009; UNDESA, 2012; World Bank, 2016). The dependent variable is migrant remittance as a share of the gross domestic product (prr). The independent variables include per capita income (PCI), food affordability index (FAI), gini coefficient index (GINDEX), the share of out-of-pocket in total health spending (OUTTHE), HIV/AIDS prevalent rate (HIV/AIDS). The variables are briefly described in Table 1. 
Table 3: data description and sources

\begin{tabular}{|c|c|c|c|c|}
\hline Variables & Description & Proxy for & $\begin{array}{l}\text { Apriori } \\
\text { signs }\end{array}$ & Source (s) \\
\hline $\begin{array}{l}\text { Life expectancy rate } \\
\text { (LER) }\end{array}$ & $\begin{array}{l}\text { It is the number of } \\
\text { years a person can } \\
\text { expect to live. It is } \\
\text { based on an estimate of } \\
\text { the average age that } \\
\text { members of a particular } \\
\text { population group will } \\
\text { be when they will die. }\end{array}$ & $\begin{array}{l}\text { Health } \\
\text { outcomes }\end{array}$ & $\begin{array}{c}\text { Not } \\
\text { applicable }\end{array}$ & $\begin{array}{c}\text { World } \\
\text { Development } \\
\text { Indicators (WDI, } \\
\text { 2018) }\end{array}$ \\
\hline $\begin{array}{c}\text { Migrant remittances } \\
\text { as share of the Gross } \\
\text { Domestic Product } \\
\text { (PRR) }\end{array}$ & $\begin{array}{l}\text { The share of private } \\
\text { remittances in GDP }\end{array}$ & $\begin{array}{c}\text { Private } \\
\text { remittances }\end{array}$ & Positive & $\begin{array}{c}\text { World } \\
\text { Development } \\
\text { Indicators (WDI, } \\
\text { 2018) }\end{array}$ \\
\hline $\begin{array}{c}\text { HIV/AIDS prevalent } \\
\text { rate } \\
(\mathrm{HIV} / \mathrm{AIDS})\end{array}$ & $\begin{array}{l}\text { The annual percentage } \\
\text { change in consumer } \\
\text { price index }\end{array}$ & $\begin{array}{l}\text { Disease } \\
\text { burden }\end{array}$ & Positive & $\begin{array}{c}\text { World } \\
\text { Development } \\
\text { Indicators (WDI, } \\
\text { 2018) }\end{array}$ \\
\hline $\begin{array}{l}\text { Out of pocket health } \\
\text { spending as a share of } \\
\text { total health spending } \\
\text { (OUTTHE) }\end{array}$ & $\begin{array}{l}\text { It measures the share } \\
\text { of private health } \\
\text { spending in total health } \\
\text { spending. }\end{array}$ & $\begin{array}{l}\text { Healthcare } \\
\text { financing } \\
\text { burden }\end{array}$ & Negative & \begin{tabular}{l}
\multicolumn{1}{c}{ World } \\
Development \\
Indicators (WDI, \\
2018)
\end{tabular} \\
\hline $\begin{array}{l}\text { Per capita Income } \\
\text { (PCI) }\end{array}$ & $\begin{array}{l}\text { It is the average income } \\
\text { of the population }\end{array}$ & $\begin{array}{l}\text { Economic } \\
\text { well-being }\end{array}$ & Positive & $\begin{array}{c}\text { World } \\
\text { Development } \\
\text { Indicators (WDI, } \\
2018 \text { ) }\end{array}$ \\
\hline $\begin{array}{l}\text { Food affordability } \\
\text { Index } \\
\text { (FAI) }\end{array}$ & $\begin{array}{l}\text { It is the ratio of average } \\
\text { wages to the price of } \\
\text { one individual food } \\
\text { items or a combination } \\
\text { of items. }\end{array}$ & $\begin{array}{l}\text { Availability } \\
\text { of food }\end{array}$ & Positive & $\begin{array}{c}\text { World } \\
\text { Development } \\
\text { Indicators (WDI, } \\
\text { 2018) }\end{array}$ \\
\hline $\begin{array}{l}\text { Gin coefficient Index } \\
\text { (GINDEX) }\end{array}$ & $\begin{array}{l}\text { It is a measure of } \\
\text { dispersion intended to } \\
\text { represent income } \\
\text { inequality or wealth } \\
\text { inequality within a } \\
\text { nation or any other } \\
\text { group of persons. }\end{array}$ & $\begin{array}{l}\text { Equality of } \\
\text { income } \\
\text { distribution }\end{array}$ & Negative & $\begin{array}{c}\text { World } \\
\text { Development } \\
\text { Indicators (WDI, } \\
\text { 2018) }\end{array}$ \\
\hline
\end{tabular}

Source: Authors' compilation 


\section{Results and discussion}

\subsection{Descriptive Statistics and Correlation Matrix}

In Table 4, the descriptive statistics of the variables is presented. HIVAIDS prevalent rate has an average value of 1.673 , with minimum and maximum values of -36.556 and 18.053 respectively while the standard deviation is 4.212 , skewness is -3.097 and kurtosis is 26.799 . Similarly, inflation rate has an average value of 5.987 , with minimum and maximum values of -4.294 and 37.142 respectively while standard deviation is 6.096, skewness is 1.902 and kurtosis is 8.039. Out- of pocket share of total health spending (OUTTHE) has an average value of $28.504 \%$ and, with minimum and maximum values of 0.00 and $78.666 \%$ respectively; skewness and kurtosis are respectively 0.349 and 2.013. Per Capita Income (PCI) has an average value of 5153.86, with minimum and maximum values respectively of 646.295 and 36576.09 , while standard deviation of 6343.173, skewness and kurtosis respectively are 2.555 and 9.941. Ginindex (GINDEX) has an average value of 5.048, with minimum and maximum values respectively as 0.000 and 63.400, while the standard deviation is 14.148; skewness and kurtosis are respectively 2.571 and 8.069 . Finally, the average value of life expectancy rate at birth is 55.517, with minimum and maximum values respectively as 12.500 and 54.800 , while standard deviation is 23.408 ; skewness and kurtosis are respectively 0.864 and 4.635. An examination of the Jarque-Bera Statistics showed that all the macroeconomic variables are statistically significant at $1 \%$, hence they are all normally distributed. Average (mean) personal remittances received as a percentage of GDP within the period was $4.35 \%$. Period maximum was $31.50 \%$, while period minimum was $0.003 \%$.

Table 4 Descriptive Statistics of Principal Variables

\begin{tabular}{|l|c|c|c|c|c|c|c|c|}
\hline Variables & Mean & Max & Min & Std. dev. & Skewness & Kurtosis & J.B. & Probability \\
\hline HIV/AIDS & 1.673 & 18.053 & -36.556 & 4.212 & -3.097 & 26.799 & 8441.4 & 0.000 \\
\hline PRR & 5.987 & 37.142 & -4.294 & 6.096 & 1.902 & 8.039 & 556.444 & 0.000 \\
\hline OUTTHE & 28.504 & 78.666 & 0.000 & 23.268 & 0.349 & 2.013 & 20.401 & 0.000 \\
\hline PCI & 5153.86 & 36576.09 & 646.295 & 6343.173 & 2.555 & 9.941 & 1036.921 & 0.000 \\
\hline FAI & 24.707 & 67.511 & 0.000 & 19.651 & 0.415 & 2.166 & 19.323 & 0.000 \\
\hline GINDEX & 5.048 & 63.400 & 0.000 & 14.148 & 2.571 & 8.069 & 723.465 & 0.000 \\
\hline LER & 55.517 & 54.800 & 12.500 & 23.408 & 0.864 & 4.635 & 78.509 & 0.000 \\
\hline
\end{tabular}

Source: Author's computation using eviews 8.0

\subsection{Results from Pooled Ordinary Least Square and Fixed Effect Models}

The econometric result from the pooled, fixed effects and random effects regression model for the sampled 5 countries between 1990 and 2020 are shown 
in Table 5. The table contains the estimated parameters, and the probability values (in parenthesis). This study made use of the random effects model of estimation, the Hausman test was conducted to decide between the fixed effects and the random effects. Based on the probability value of the Hausman test, the random effect model was chosen to be the most appropriate estimator. The results from the Random effect model are similar to that of the ordinary least square results. The result showed that a unit rise in HIV/AIDS prevalent rate will cause life expectancy rate to rise by $0.748 \%$. This implies that HIV/AIDS burden in WAMZ accounts low life expectancy rate. Also, a 1\% rise in migrant remittance as a share of the GDP will cause life expectancy rate to rise by $0.133 \%$. Also, out-ofpocket health spending as a proportion of total health spending has significant negative impact on life expectancy rate at birth. Hence if out-of-pocket health spending as a share of total health spending rises by $1 \%$ then life expectancy rate at birth will decline by $0.393 \%$. On the other hand, per capita income maintained significant positive impact on life expectancy rate at birth. A 1\% rise in Per Capita Income will cause life expectancy rate at birth to increase by $0.001 \%$. Food availability index has significant positive impact on life expectancy rate at birth. Gini coefficient index has negative impact on life expectancy rate at birth. Thus, higher income inequality rather reduces life expectancy rate at birth.

Table 5: Fixed effects and ordinary least square results for LER for WAMZ countries

\begin{tabular}{|c|c|c|c|}
\hline Variables & Pooled OLS & $\begin{array}{c}\text { Fixed effects } \\
\text { Results }\end{array}$ & Random Effects \\
\hline Ln HIV/AIDS & $\begin{array}{c}-0.748 \\
(0.005)^{*}\end{array}$ & $\begin{array}{c}0.212 \\
(0.004)^{*}\end{array}$ & $\begin{array}{c}-0.748 \\
(0.005)^{*}\end{array}$ \\
\hline Ln PRR & $\begin{array}{l}0.1329 \\
(0.455)\end{array}$ & $\begin{array}{c}-0.155 \\
(0.014)^{* *}\end{array}$ & $\begin{array}{c}0.133 \\
(0.000)^{*}\end{array}$ \\
\hline Ln OUTTHE & $\begin{array}{c}0.3934 \\
(0.000)^{*}\end{array}$ & $\begin{array}{c}0.096 \\
(0.000)^{*}\end{array}$ & $\begin{array}{c}-0.393 \\
(0.000)^{*}\end{array}$ \\
\hline Ln PCI & $\begin{array}{c}-0.001 \\
(0.000)^{*}\end{array}$ & $\begin{array}{l}0.000 \\
(0.235) \\
\end{array}$ & $\begin{array}{c}0.001 \\
(0.000)^{*}\end{array}$ \\
\hline Ln FAI & $\begin{array}{l}-0.2640 \\
(0.000)\end{array}$ & $\begin{array}{c}0.04 \\
(0.042) * *\end{array}$ & $\begin{array}{c}0.264 \\
(0.000) *\end{array}$ \\
\hline Ln GINDEX & $\begin{array}{c}-0.1389 \\
(0.073)^{* * *}\end{array}$ & $\begin{array}{l}0.015 \\
(0.451)\end{array}$ & $\begin{array}{c}-0.139 \\
(0.073) * * *\end{array}$ \\
\hline$R 2$ & 0.291 & 0.963 & 0.292 \\
\hline Adjusted R2 & 0.278 & 0.958 & 0.278 \\
\hline F-statistics & 21.87 & 177.4 & 21.875 \\
\hline Probability & 0.000 & $0.000^{*}$ & $0.000^{*}$ \\
\hline Hausman Test Chi2= & $252 \quad$ Prob > & 2039 & \\
\hline
\end{tabular}

Source: author's computation using eviews 8.0 , where ***, ** and * indicate significance at 1,5 and 10 per cent levels respectively. Values in parentheses are probability values

Year XXIV no. 81

September 2021 


\subsection{Results from the Pooled Mean Group Estimator}

The Pooled Mean Group estimates are presented in Table 6. In this section, we identified the short and long-run variables that influence life expectancy rate among the WAMZ countries with migrant's remittance as a share of the GDP as the key explanatory variables using PMG estimator. PMG is very helpful in this instance as it involves both pooling and averaging, hence it allows for both shortrun heterogeneous dynamics and long-run homogeneous relationships for countries of WAMZ. Being an autoregressive distributed lag model due to a lag sensitivity, we imposed a lag length of 1 using Hannan-Quinnn criterion to optimum lag selected automatically for the various variables (Iseghohi, 2021). Essentially, the results showed both short and long-run effects of migrant remittances on life expectancy rate at birth for WAMZ. The result conforms to the report by Uzochukwu and Chuwkunonso (2018) that remittance is an important factor in accelerating improvements in health and education in recipient countries. In a systematic review, Nathaniel (2019) reported that remittance has come a long way in assisting low income earners access health services. According to him, remittance has played pivotal role in facilitating access to health services in poor resource settings where there is low universal health coverage for health. For instance, in SSA in which WAMZ is part, out-of-pocket health spending is the main source of financing health and given the high rate of poverty, many households cannot pay for healthcare services. Hence, in this type of settings remittance serves as alternative source of resources to fund health and education (Nathaniel, 2019; Uzochukwu and Chukwunonso, 2018).

Table 6: PMG estimates for WAMZ, one lag $(1,1,1,1,1,1,1,1)$.

\begin{tabular}{|l|c|c|c|}
\hline \multicolumn{1}{|c|}{ Variables } & Estimated coefficients & T statistics & Probability \\
\hline \multicolumn{3}{|c|}{ Long-run Equation } \\
\hline Ln HIV/AIDS & -0.012 & 3.537 & $0.001^{*}$ \\
\hline Ln PRR & 4.003 & 4.300 & $0.002^{*}$ \\
\hline Ln OUT/THE & -3.034 & 3.935 & $0.051^{* * *}$ \\
\hline Ln PCI & 3.000 & 3.363 & $0.012^{* *}$ \\
\hline Ln FAI & 0.040 & 3.818 & $0.000^{*}$ \\
\hline Ln Gindex & -9.878 & 2.897 & $0.089^{* * *}$ \\
\hline \multicolumn{3}{|c|}{ Short-run Equation } \\
\hline Cointeq01 & 0.056 & 2.568 & $0.011^{* *}$ \\
\hline DLn HIV/AIDS & -0.897 & 3.456 & $0.000^{*}$ \\
\hline DLn PRR & 9.896 & 2.345 & $0.000^{*}$ \\
\hline DLn OUT/THE & -2.456 & 4.567 & $0.000^{*}$ \\
\hline DLn PCI & 0.545 & 2.567 & $0.002^{*}$ \\
\hline DLn FAI & 2.567 & 0.768 & 0.567 \\
\hline DLn Gindex & 1.456 & 0.987 & 0.564 \\
\hline
\end{tabular}

Year XXIV no. 81

September 2021 
Source: author's computation using eviews 8.0 , where $* * *, * *$ and $*$ indicate significance at 1,5 and 10 per cent levels respectively. Values in parentheses are probability values

\section{Conclusion and policy recommendations}

This study assessed the impact of migrant remittance on health for countries of WAMZ. Panel data set for the period (1990-2018) was used for the analysis. Pooled Ordinary least square, fixed effect model and random effect models were estimated as baseline models. Further, the pooled mean group was estimated using optimum lag of one. Health was proxy by life expectancy rate at birth. The pooled mean group estimates showed that migrant remittance as a share of the GDP has significant positive impact on life expectancy rate in both short and long-run. Hence, migrant remittance is a significant factor in accelerating improvements in health in the WAMZ. It is, therefore, important that policy makers in WAMZ countries should articulate appropriate policies to create incentives for migrants to remit, especially policies that influence costs and channels of remittances. Also reducing the burden of HIV/AIDs and look for alternative means of financing health besides out-of-pocket health spending will positively influence life expectancy rate. Improving household income will yield health dividend by improving life expectancy rate at birth. Policies should be articulated that boost income-earning opportunities by improving household per capita income.

\section{References}

Adam, R.H. (2007). The determinants of international remittances in developing countries. World Development 37(1): 93-103.

Adolfo, C., Fullenkamp, R., Gapen, C. M. \& Peter, M. (2009). Macroeconomic Consequences of Remittances. IMF Occasional Paper, Washington DC.

Alkabir, F., Khan, F., \& Amm, S.B. (2018). Impact of remittances on enrolment and healthcare. The case of Bangladesh. World Review of Business Research, 8(2):56-66.

Amuedo-Dorantes, C., \& Pozo, S. (2004). Workers' remittances and the real exchange rate: a paradox of gifts. World Development 32(8):1407-1417. Doi:10.1016/j.worlddev.2004.02.004.

Anyanwu, J.C., \& Erhijiakpor, A.E. (2009). Health expenditure and health Outcomes in Africa. Africa Development Review, 21(2):400-433.

Carling, J. (2008). Interrogating Remittances: Core Questions for Deeper Insight and Better Policies. In: Migration and Development: Perspectives from the South (S. Castles and R.D. Wise, eds.). Geneva: International Organisation for Migration, 43-64.

Year XXIV no. 81

September 2021 
Filmer, D., \& Pritchett, L. (1997). Child mortality and public spending on health: does money matter? Social Science and Medicine, 49(10): 1309-1323.

Gujarati, D.N., and Porter, D.C. (2009). Basic Econometrics $5^{\text {th }}$ Edition, McGrawHill Inc. New York.

Gupta, S. \&Waghs, (2007). Effect of Remittance on Poverty and Financial Development in Sub-Saharan Africa. World Development, 39(1):104-115.

Harrison, A. (2004). Working Abroad- the Benefits Flowing from Nationals Working in other Countries. Paper presented at the Round Table on Sustainable Development, OECD.

Iseghohi, J.O. (2020a). Determinants of migrants' remittances in the West Africa Monetary Zones (WAMZ). Journal of Research in humanities and social sciences, 9(1):87-95.

Iseghohi, J.O. (2020b). Migrant's remittances and economic growth in the West Africa Monetary Zones. Romanian Economic Journal, XXII (78):47-66.

Iseghohi, J.O. (2021). Do migrants' remittances significantly reduce poverty in the West Africa Monetary Zone (WAMZ)? Journal of Economics and Finance, 2(6):35-44.

Lopez-Cevallos, D.F., \& Chi, C. (2012). Migration, remittances and healthcare utilization in Ecuador. Revista Panamericans Desclud Publica, 31(1):9-16.

Murugarra, E. (2002). Transfers and migrant's remittances: Evidence from the recent Armenia experience. World Bank Economist' Forum, 2:25-47.

Nixon, J., \& Ulmann, P. (2006). The relationship between healthcare expenditure and health outcomes. The European journal of Health Economics, 7(1):7-18.

Nathaniel, A.O. (2019). Impact of remittance on healthcare utilization and expenditure in developing countries: A systematic review. Rwanda Journal of Medicine and Health sciences, 2(3): 304-310. https://doi.org/10.4314/rjmhs.v213.15.

Ponce, J., Olive, I., \& Onota, M. (2018). The role of international remittances in health outcomes in Ecuador: Prevention and response to shocks. International Migration Review. Https: doi.org/10.1111/j.17477379.2011.00864.X.

Quartey, (2006). Remittances and Poverty in Ghana. World Bank Policy Research Paper3838 Washington DC: World Bank.

Ratha, D. (2011). South-South Migration and Remittances, Washington D.C: World Bank.

Reassne, F., Oswaldo, P., Dolores, A., Juan, R., Gustavo, O., \& Claudia, D. (2009). The relationship between remittances and health care provision in Mexico. America Journal of Public Health 99 (71): 1227-31. Doi.10.2105/AJPH.2008.144980. 
Rubyutsa, J.(2012). The role of remittances in development: the case of Rwanda Diaspora's remittances. Rwanda Journal, 26(1): 120-32.

Sede, P.I., \& Ahuru, R.R. (2017). Socioeconomic context of reproductive health outcomes in Nigeria. Amity Journal of Economics 2(1); 1-22.

UNDESA (2012). World Economic and Social Survey 2012, New York: United Nations Department of Economic and Social Affairs.

UNDP (2009). Human Development Report 2009: Overcoming Barriers: Human mobility and development, New York and Basingstoke: UNDP and Palgrave Macmillan.

Uzochukwu, A. \& Chukwunonso, G.I. (2014). Impact of migrant remittances on health and education outcomes in sub-Saharan Africa. ISOR Journal of Humanities and Social Sciences (IOSR-JHS), 9(8): 33-34.

World Bank (2014). Remittances to Developing Countries to Stay Robust this Year Despite Increasing Deportation of Migrant Workers says World Bank. Retrieved from http://www.wb.org on December 20, 2017.

World Bank (2015). World Development Indicators, Washington, DC: World Bank.

World Bank (2016). World Development Indicators, Washington, DC: World Bank.

Yao, L., and Treiman, D.J. (2007). Effect of labour migration and remittances on children's Education and blacks in South Africa. CCPR working paper 001-97, California. Centre for Population Research, Los Angeles, University of California. 